\title{
Method and Its Culture: An Historical Approach
}

WILLIAM E. DOLL, Jr.

Louisiana State University (USA)

Imposing an alleged uniform general method upon everybody breeds mediocrity. (Dewey. 1916/1966)

In the above quote, John Dewey, like others such as his contemporary A.N. Whitehead, worries about imposing a uniform general method-much akin to what educators do in "methods courses." Whitehead (in Price, 1954) worried about this universalization of practical habits so much that he even railed against "good teaching"; for such teaching, carrying with it the concept that "this and this are the right things to know," rigidifies learning and creates "thought [that] is dead" (p.63). Building upon the quote already given, Dewey $(1916 / 1966)$ states that "to suppose that students ... can be supplied with models of method to be followed ... is to fall into a self-deception that has lamentable consequences" (p. 172). And these consequences are those of "imposing intellectual blinders upon pupils-restricting their vision to the one path the teacher's mind happens to approve" (p.175).

The history of this imposition, of this one right way - "the one and only way... Aristotle taught" — goes back centuries to Petrus Ramus (1515-1572) and his simplified view of both curriculum design and methods of presenting that design (Triche \& McKnight, 2004; Doll, Fleener, Trueit, \&St. Julien, 2005, 
ch. 1). The word method is a combination of the Greek meta (follow) and odos (way); hence, "following a way." Systematizing, universalizing, rigidifying this way is, though, as the Oxford English Dictionary (1989, vol. IX) points out, "foreign to Greek: it was developed through the special application of Latin method [methodus] by some logicians in the $16^{\text {th }}$ century" (p. 690). Ramus, a Catholic with Protestant leanings, was one of those logicians. The fact that Ramus was of a Protestant persuasion is important, for it was the Puritans of northern Europe with their love of piestic "simplicité" who brought the concept of method we know to America.

In colonial America, Ramist logic became a featured part of Harvard College, with virtually all thesis during the $17^{\text {th }}$ century utilizing his "method." As Perry Miller (1953) points out, Ramist methods were most important in forming the New England Mind. Increase Mather forever enshrined Ramus in that Mind when he called Ramus "that Great Scholar and Beloved Martyr" (p. 117). Method, as an "ism though," was a movement much larger than Ramus. It was prominent not only in ecclesiastical circles but was prominent in the writings of John Amos Comenius, Francis Bacon, Galileo Galilei, and René Descartes, to name but a few. John Bunyan, in his "Apology" for The Pilgrim's Progress, says that "having now my Method ... so I penned it down; until it came to be" (the length and breadth of which you see); while the philosopher Gottfried von Liebniz stated that "nothing can escape our method ... it spares the mind and the imagination" (all cited in Doll et al., 2005, ch.1). Peter Dear (1995), writing on this time period and especially on the methodization movement then in vogue, states that "by the end of the sixteenth century," humanist scholars, mostly of a Protestant persuasion, "had their own functional equivalent of the [Catholic] Holy Spirit." It was Method (p. 121; emphasis added).

Considering that "method" was an idea run rampant in both northern Europe and Colonial America in the $16^{\text {th }}$ through $18^{\text {th }}$ centuries-not to mention its prominence in the industrialization movement of the centuries following - it should be no surprise to find it in educational textbooks today. In fact, the union between method and textbooks can be traced back to Peter Ramus and the shortcuts he took to display (or chart) all knowledge for students to learn. As useful as this strategy was in the late Renaissance ages-and compared to the abstract intricacies of scholasticism -it has left us with a legacy which assumes that knowledge can, and indeed should, be presented efficiently: in concise, simplified, methodized form. Ramus, the prime designer of this form, was, as Walter Ong (1983) states, "the greatest master of the short-cut the world has ever known" (p. 3). Textbooks, an inheritance of this legacy, by their very design and presentation are organized to provide us with a short-cut to knowing. 
Knowledge memorized is substituted for the act of knowing. The mimetic is substituted for the poietic - copying for creating (Trueit, 2005).

What is surprising, after all these centuries, is that method has retained its original rigidity. The abiding effect of Ramus' phrase- - "the one and only way" - existent in our current sense of method, is really quite opposed to what John Dewey was advocating when he brought forth (1910/1933) the concept of a "scientific method" for the social sciences, including education. What Dewey was after was not a set, multiple (usually five) step procedure, but rather a way of experimenting, of looking at and for alternatives to any problem (Doll, 2001). What an irony! And is it any wonder the ghost of Dewey haunts us still (Doll \& Gough, 2002).

\section{A New Sense of Method}

In Democracy and Education (1916/1966), not only does Dewey make negative comments about the "intellectual blinders" imposed, universalized and set methods put on students, but he also talks, quite positively, about the need for students to develop their own personal habits (methods) of thought and action-guided by the experiences of others. In short, the relationship between personal methods and those of others is an interactional one. There is a dialogue (or conversation in Donna Trueit's sense) between one's personal habits / methods and those of others, especially experienced others. Again, as Trueit (2005) points out, Dewey's frame is poietic not mimetic, creative not copied. Dewey brings forth this interactive relationship in the following quotes, interspersed with the "intellectual blinders" quotes already stated:

Part of learning, a very important part, consists in becoming master of the methods which the experience of others has shown to be more efficient in the cases of getting knowledge. These general methods are in no way opposed to individual initiative and originality-to personal ways of doing things. (p. 171; emphasis added)

And a few pages later he states:

The specific elements of an individual's method or way of attack on a problem are found ultimately in his native tendencies and his acquired habits and interests. (p. 173; emphasis added)

Note here please the distinction between general and individual methods. Looking at others' methods promotes a general not specific plan. Specific situations require individual "initiative and originality".

With our culture of method, stretching from Ramus to the present day, it is easy to misread Dewey here, especially in the first quote above. But over and over, Dewey's point about the importance of inter (or trans) action 
is that there needs to be a reflective (or following Sarah Smitherman, 2006, a complex) conversation between one's "native tendencies and acquired habits" and the situations/environments in which those habits are embedded. Our challenge as educators is to help guide these conversations so that one's acquired habits focus on the creative not the copied. The new sciences of chaos and complexity may indeed provide us an entrée into that which Dewey so desired yet so poorly articulated. These sciences have a sense of method but one "notably free" of what Richard Rorty (1999) calls "methodolotry" - that is, a deification of method. Here, especially in the process of recursive iteration, a situation (or mathematical sentence) is looked at not only in terms of itself, but also in terms of its relationship with the situation (or sentence) from which it emerged, and in terms of that which has yet-to-emerge. In this emergent approach, method has a flexibility, an openness, not found in Ramus' (or indeed Ralph Tyler's) approach. Goals, purposes, and values are neither pre-set nor universal, but actually emerge from the interactional practices in situ; and in this emergence lies the fermentation of creativity. Our challenge as educators is not so much to design tracks for our students to follow, nor to keep the students "on track," but rather to work with our students in helping them explore the multiple pathways which connect and create.

The idea that ... we can substitute "method" for deliberation ... is just wishful thinking. (Rorty, 1982)

If the philosopher follows a method or a school, the philosopher dies in the rigidity of dogma. (Serres, 1997)

\section{References}

Dear, P. 1995. Discipline and experience. Chicago: University of Chicago Press.

Dewey, J. 1910/1933. How we think. Boston: Heath.

Dewey, J. 1916/1966. Democracy and education. New York: Free Press.

Doll, W.E. 2001. Beyond methods: Teaching as an aesthetic and spiritful quest. In E.

Mirochnik \& D. Sherman (Eds), Passion and pedagogy (pp. 127-151). New York: Peter Lang.

Doll, W.E, Jr., Fleener, M.J., Trueit, D., \& St. Julien J. 2005. Chaos, complexity, curriculum, and culture. New York: Peter Lang.

Doll, W.E. \& Gough, N. 2002. Curriculum visions. New York: Peter Lang.

Miller, P. 1953. The New England mind. Cambridge, MA: Harvard University Press.

Ong, W. 1958/1983. Ramus, decay, and the death of dialogue. Cambridge, MA: Harvard University Press.

Oxford English Dictionary. 2nd edition, 1989. Oxford, UK: Clarendon Press.

Price, L. 1954. Dialogues with Alfred North Whitehead. Boston: Little Brown.

Rorty, R. 1982. Consequences of pragmatism. Chicago: University of Chicago Press.

Rorty, R. 1999. Philosophy and social hope. London: Penguin. 
Serres, M. 1997. Troubadour of knowledge. Shelia Glaser, Trans. Ann Arbor, MI: University of Michigan Press.

Smitherman, S. 2006. Reflections on teaching a mathematics education course. Unpublished doctoral dissertation. Baton Rouge, LA: Louisiana State University.

Triche, S., \& McKnight, D. The quest for method: The legacy of Peter Ramus. Journal of History of Education 33(1): 39-54.

Trueit, D. 2005. Complexifying the poetic: Toward a poiesis of curriculum." Unpublished doctoral dissertation. Baton Rouge, LA: Louisiana State University.

\section{About the Author}

Wm. Doll is the Vira Franklin and J.R. Eagles Professor of Curriculum at Louisiana State University, where he co-directs the Curriculum Theory Project and coordinates the Holmes Elementary Education teacher education program. His research interests include curriculum theory and design, chaos and complexity theories, cognition, mathematics education, the history of education, and education on a transnational scale. [e-mail: wdoll@lsu.edu]

(C) Copyright 2006. The author, William E. Doll Jr., assigns to the University of Alberta and other educational and non-profit institutions a non-exclusive license to use this document for personal use and in courses of instruction provided that the article is used in full and this copyright statement is reproduced. The authors also grant a non-exclusive license to the University of Alberta to publish this document in full on the World Wide Web, and for the document to be published on mirrors on the World Wide Web. Any other usage is prohibited without the express permission of the authors. 
